\title{
From Eastern Bloc to European Union : Comparative Processes of Transformation since 1990
}

\section{Laanes, Liia}

2019-05-31

Laanes , L 2019 , ' From Eastern Bloc to European Union : Comparative Processes of

Transformation since 1990 ' , Europe - Asia Studies , vol. 71 , no. 4 , pp. 708-709 . https://doi.org/10.1080/09668136

http://hdl.handle.net/10138/322153

https://doi.org/10.1080/09668136.2019.1610283

acceptedVersion

Downloaded from Helda, University of Helsinki institutional repository.

This is an electronic reprint of the original article.

This reprint may differ from the original in pagination and typographic detail.

Please cite the original version. 
Liia Laanes

\section{Heydemann, Günther \& Vodička, Karel (eds), From Eastern Bloc to European Union. Comparative Processes of Transformation since 1990. New York, NY: Berghahn Books, 2017, xvi + 397pp., £92.00/\$130.00 h/b.}

Following the collapse of communist-authoritarian regimes in Central and Eastern Europe during the end of the 1980s and beginning of the 1990s, different countries have followed different paths and a different pace of transformation. There are not many books which would give both an overview of all the three aspects of transformation (political, economic and social transformation) and which would cover more than a limited number of countries. The collection edited by Heydemann and Vodička attempts to fill this gap. The book is a translation from a German-version that was published in 2013, though some chapters have been visibly updated (e.g. Chapter 3 on Lithuania contains a reference to the year 2015). According to the authors, the book 'attempts to satisfy a need for information at levels as disparate as policy-making and school-teaching' (p.5) and it seems to do this.

The book is comprised of 11 chapters (Chapters 1 to 11), written by different authors and each covering a different country, plus an Introduction and a Conclusion written by the editors. The countries covered are the ten Eastern Bloc countries that joined the European Union (EU) in 2004 and 2007 - Estonia, Latvia, Lithuania, Poland, Czech Republic, Slovakia, Slovenia, Hungary, Romania and Bulgaria - and the former German Democratic Republic (GDR).

The period primarily covered is from 1990 through 2012, though some chapters go even further back in time to provide relevant background information. All the chapters cover more or less the same aspects: under the three main headings (politics, economy, and society) there are descriptions of certain aspects like political and legal system, privatisation, political parties, civil society, and the media (to name a few).

The chapter on the GDR (Chapter 4) provides a reader with an interesting comparative analysis between East and West Germany and shows how the East and West of the Federal Republic of Germany have kept their different political cultures well after the successful reunification. Chapter 9, in conjunction with the Conclusion, also sheds light on the roots of current developments and problems in Hungary, when it comes to democracy. The editors 
conclude that, while EU membership does not guarantee absolute protection from derogations of the quality of democracy, without the EU mechanisms and pressure from other EU countries, this quality loss would be 'more dramatic' (p. 349).

Contributions, covering more or less the same aspects, enable to present in the Conclusion a comparison of the countries. The basis for the comparison is the consolidation model developed by Wolfgang Merkel and the chapters about each country. The consolidation model 'distinguishes four levels of consolidation: constitutional consolidation, representative consolidation, consolidation of behaviour, and consolidation of civil society' (p. 307). Heydemann and Vodička have decided to use, as reference, the countries of Austria, the Netherlands, and West Germany. The authors emphasise that a distortion of political culture by the communist rule has not been revised by 2012 and, hence, the core problem of transformation is changes in mentality. The political culture helps to explain, for instance, corruption, a somewhat low satisfaction with actual democracy, and low trust in political parties. Relics of democratic political culture have survived in the countries that experienced democracy in the interwar period and it has increased their chances to re-establish democracy (p. 307).

The Conclusion provides several very good graphs to offer a comparative snapshot of the 11 countries and reference countries. However, in the case of some graphs (e.g. Figure 12.4), the comparability between countries or over the years raises some doubts as the underlying data sources for different countries or years are different.

The strength of the book lies in its scope, as already indicated. Furthermore, the book and chapters are wellstructured, which means that if a reader is interested only in specific aspects, he or she can find these easily without a need to read the whole book. As the majority of the authors are Germans, the bibliography mainly contains sources written in German.

The weakness of the book is its (numerical) accuracy. For instance, in Chapter 1, it is stated that in Estonia the President is elected for four years and the Chancellor of Justice for life (pp. 11-12), while in reality the former is elected for five years and the latter is appointed for seven years. There are also some mistakes in years or rankings in several other chapters. Therefore, the book is more useful as a general reference book providing a general overview of the countries, than as a reliable source of statistical/numerical data. 
Despite the shortcomings, the compilation serves its purpose as a handbook, providing the overall glimpse of economic, political and social transformation in the selected 11 countries. It is a valuable source to understand general developments in different countries and as an excellent starting point for not only students or scholars who are entering into this field of study, but also for general audience to understand the political, economical and social success stories or challenges of the selected countries. 